<綜 説 >

（受理 : 平成 13 年 7 月 2 日）

\title{
電子部品組立用接着剂とその応用 Adhesives for Electronic Assemblies
}

柳 原 栄 - *

Eiichi YANAGIHARA

\section{1.はじめに}

組立作業における接着剤の利用は電子・電気機器のみ ならず自動車や航空機など, 多くの産業分野で一般的に 行われている。これは部品や製品の小形化・軽量化・高 機能化などの目的に, 接着接合の利点を活用することが 不可欠となっていることにある。また，20 世紀の高分 子化学の発展により, 数多くの優れた接着剤が開発され た成果でもある。

電子部品・機器の組立には各種の接着剤が使用されて いるが，その使用量は国内生産量の $1 \%$ 強である。しか し, 接着風への要求は多項目にわたっているこから, 採 用の際の評価に時間を要することが多い。

ここでは電子部品・機器の組立に使用している接着剤 を紹介するが, すでにいくつかの解説もあり ${ }^{1 \sim 5)}$, 詳細 はそれらをお読みいただきたい。

\section{2. 接着剤への要望}

接着剤として用いるのであるから接着強さへの要望が 第一に挙げられるが, 接着強さ以外に表 1 に示したよう な特性のいくつかを同時に必要とされることもある。

電気特性では絶縁性に加えて誘電率や誘電損失の大小 が性能の上から問題となることがある。導電性粒子を配 合した導電性接着剤が，はんだの代替として適用が増加 している。化学的特性では導体として用いる薄膜金属へ の腐食性のないことや吸湿性の大小がある。光学特性に は光の透過率や屈折率などがある。熱的特性では接着強 さの温度依存性の少ないことや発熱部品からの放熱に熱

\footnotetext{
*神奈川県技術アドパイザー

横浜市泉区西が岡 1-5-5 テ 245-0006

Technical Advisor to Kanagawa Prefecture

1-5-5 Nishigaoka Izumi-ku Yokohama Kanagawa 2450006 Japan
}

表 1 電子・電気機器用接着剤に要求される特性

\begin{tabular}{l|l}
\hline 電気的 & $\begin{array}{l}\text { 絶縁性 } \\
\text { 䅎電特性 } \\
\text { 耐電圧性 } \\
\text { 等電性 }\end{array}$ \\
\hline 化学的 & $\begin{array}{l}\text { 非腐食性 } \\
\text { 低吸湿性 } \\
\text { 難燃性 }\end{array}$ \\
\hline 機械的 & $\begin{array}{l}\text { 低熱膨張性 } \\
\text { 寸法安定性 }\end{array}$ \\
\hline 光学的 & $\begin{array}{l}\text { 屈性率 } \\
\text { 透明性 }\end{array}$ \\
\hline 熱 的 & $\begin{array}{l}\text { 安定性 } \\
\text { 伝等性 }\end{array}$ \\
\hline
\end{tabular}

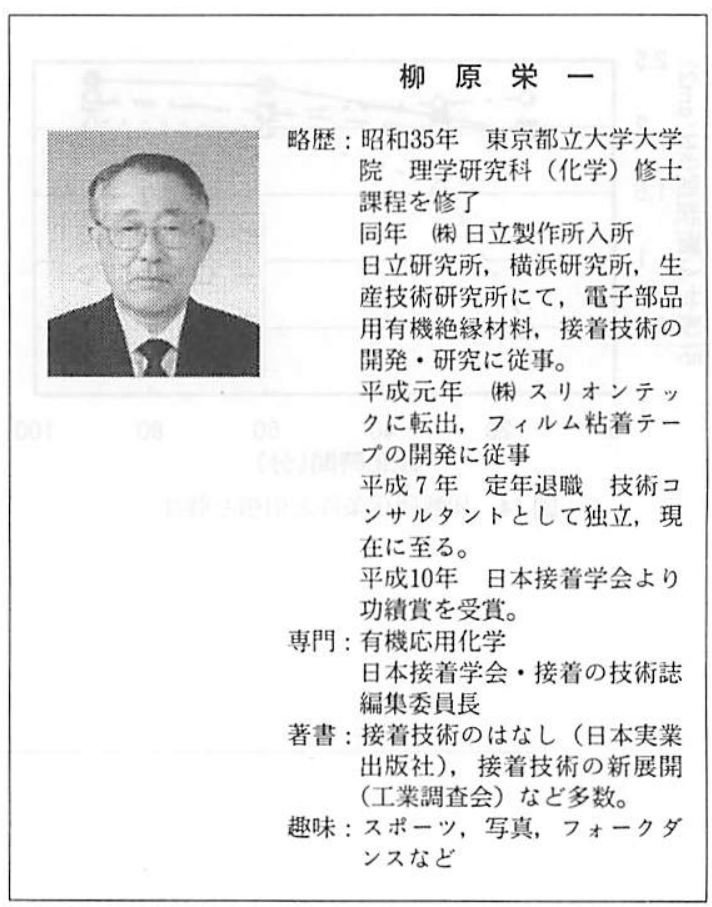


表 2 作業面から接着剂に要求される特性

1 液性であること

無溶剤であること

洼布の自動化が可能なこと

表面状態の影鄀の受け難いこと

保存安定性の良いこと

短時間に固化・硬化すること

低温での硬化が可能なこと

表 3 短時間に固化・硬化する接着剤の特性

\begin{tabular}{l|c|c}
\hline \multicolumn{1}{c|}{ 接着 阂 } & $\begin{array}{c}\text { 発現時間 } \\
\text { (室温) }\end{array}$ & $\begin{array}{c}\text { 接着強さ } \\
(\mathrm{MPa})\end{array}$ \\
\hline シアノアクリレート & $2 \mathrm{sec}$ & 20 \\
紫外線硬化系 & $2 \mathrm{sec}$ & 20 \\
第2世代アクリル & $2 \sim 5 \mathrm{~min}$ & 20 \\
エポキシ樹脂 & $5 \mathrm{~min}$ & 15 \\
ポリウレタン & $1 \mathrm{~min}$ & 10 \\
ホットメルト系 & $2 \mathrm{sec}$ & 5 \\
クロロプレン系 & $5 \mathrm{~min}$ & 1 \\
両面粘着テープ & $2 \mathrm{sec}$ & 1 \\
\hline
\end{tabular}

\section{伝導性が求められる場合もある。}

また, 寸法精度を必要とする部品では，接着斉の熱膨 張率や吸湿性の大小も部品の経時特性に影㗽がある。

一方，作業性の観点から見ると表 2 に示したような特 性が求められている。生産性の面からは短時間に固化・ 硬化する接着剤への要望が大きい。また，小さな部品が 多いことから微量の接着剤を自動塗布する課題がある。 表 3 に短時間に固化・硬化するいくつかの接着剤を示し た。1液性で紫外線の照射により短時間に硬化する接着 剤や両面粘着テープなどの適用が増加している。メルカ プタンを用いた短時間に硬化するエポキシ樹脂は, 硬化 物の柔軟性や吸湿性が大きいので注意が必要である。

\section{3. 電子部品組立用接着剂の種類}

接着剤メーカーから数多くの接着剤が市販されている が, 電子部品の組立に用いられている接着剤には表 4 に 示したようなものがある。このように種類が多い理由と して, 接着する材料（被着材）が木材. 金属, プラスチッ ク,ゴム，七ラミックスなど多種類にわたり，そのため 使用目的に適した接着剤が開発されており, 適切な接着 剂の選択が求められる。

ここでは代表的ないくつかの接着剤について，その内 容と特性について紹介する。

\section{1 精密部品用接着剤 ${ }^{6)}$}

組立た部品がミクロン単位の精度を必要とするむのに 用いるもので, 接着剤にはエポキシ樹脂系と光硬化接着 凬の一部が該当する。
表 4 電子・電気機器用接着剂のいろいろ

\begin{tabular}{|c|c|}
\hline 接 畕 剂 & 特 \\
\hline $\begin{array}{l}\text { コムム系 } \\
\text { 酶酸ビニル系 } \\
\text { トープセメント } \\
\text { ホットメルト系 } \\
\text { 両面粘着テープ } \\
\text { シアノアクリレート } \\
\text { けん匃性 } \\
\text { SGA } \\
\text { 紫外線硬化系 } \\
\text { エポキシ樹脂系 } \\
\text { シリコーン樹脂系 } \\
\text { ポリウレタン系 } \\
\text { ポリイミト樹脂系 } \\
\text { 無機系 }\end{array}$ & 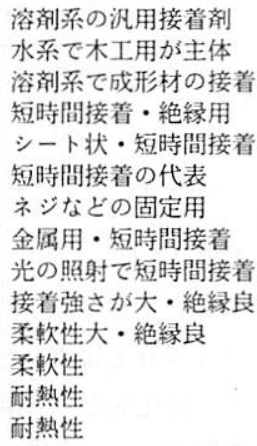 \\
\hline
\end{tabular}

1) エポキシ樹脂系

エポキシベースレジンに各種の硬化剂を組み合わせる ことで, 種々の物性を持った硬化物の得られるのが特徵 である。表 5 にエポキシ樹脂の特徴と欠点を示したが, 欠点を解消するための検討が数多くなされている。

接着風としての基本的な配合を表 6 に示したが, 硬化 剤の選択は硬化条件や硬化物の物性を左右する。ベース レジンにはビスフェノール系の液状のものが主に用いら れているが, 分子量の大きな固体のものを溶剤に溶解し て用いることもある。薄膜の金属の周辺に用いるものに は，塩素などの不純物の少ないものが望ましい。

表 5 エポキシ樹脂の特徴と欠点

\begin{tabular}{|c|c|}
\hline 特 & 欠 \\
\hline $\begin{array}{l}\text { 100\%固体となる } \\
\text { 収縮が少ない } \\
\text { 接着性に優れる } \\
\text { 電父特性に優れる } \\
\text { 耐薬品性に優れる }\end{array}$ & $\begin{array}{l}2 \text { 液性のむのが多い } \\
\text { 巢乾性に欠ける } \\
\text { 皮有刺激性のあるも } \\
\text { のがある } \\
\text { はく離に弱いものか } \\
\text { 多い }\end{array}$ \\
\hline
\end{tabular}

表 6 エポキシ樹脂接着剤の基本的な配合

\begin{tabular}{|c|c|}
\hline 成 分 & 代表例 \\
\hline ベースレジン & エピコート 828 \\
\hline 硬化剂 & $\begin{array}{l}\text { トリエチレンテトラアミン } \\
\text { ポリアミト樹脂 } \\
\text { ジアミノジフェニルメン } \\
\text { シシアンシアミト }\end{array}$ \\
\hline 希积剂 & ブチルグリシジルェーテル \\
\hline 変性偊 & CTBNなど \\
\hline 充てん剂 & シリカ, アルミナなど \\
\hline 着色剂 & カーボンブラックなど \\
\hline 消泡剂 & シリコーン化合物 \\
\hline
\end{tabular}


表 7 エポキシ樹脂系接着剤の特性と硬化剤添加量（Ep828/V-140）

\begin{tabular}{|c|c|c|c|c|c|c|}
\hline \multirow{2}{*}{$\begin{array}{l}\text { 配合量 } \\
\text { (phr) }\end{array}$ 項 } & \multirow{2}{*}{$\begin{array}{c}\text { 引張強度 } \\
\left(\mathrm{kgf} \cdot \mathrm{cm}^{-2}\right)\end{array}$} & \multirow{2}{*}{$\begin{array}{l}\text { 伸び } \\
\text { (\%) }\end{array}$} & \multirow{2}{*}{$\begin{array}{c}T_{g} \\
\text { (度) }\end{array}$} & \multicolumn{2}{|c|}{ せん断接着強度 } & \multirow{2}{*}{$\begin{array}{c}\text { 吸水率. } \\
(\%)\end{array}$} \\
\hline & & & & $25^{\circ} \mathrm{C}$ & $75^{\circ} \mathrm{C}$ & \\
\hline 50 & 580 & 2.7 & 106 & 104 & 132 & 1.4 \\
\hline 75 & 530 & 4.7 & 80 & 130 & 178 & 1.9 \\
\hline 100 & 500 & 5.8 & 63 & 160 & 96 & 3.1 \\
\hline 125 & 400 & 9.8 & 47 & 186 & 56 & 9.8 \\
\hline
\end{tabular}

$* \mathrm{Al} / \mathrm{Al}, \mathrm{kgf} / \mathrm{cm}^{2}$

$* * 25^{\circ} \mathrm{C}, 500 \mathrm{~h}, t=3.0$

室温で硬化させる場合には 1 2 級の脂肪族アミンや ポリアミドが硬化剤として用いられており，加熱硬化に は変性芳香族了ミンや 3 級アミン，イミダゾールなどの 他に, 各種の潜在性硬化剂が用いられており 1 液性とし たものも数多く開発されている。

2 液性の組成物では硬化剂の添加量によって硬化物の 物性が異なるので, 計量と混合に注意が必要である。硬 化㓮として用いたポリアミドの添加量による特性の変化 を表 7 に示した6)。

2) 紫外線硬化系 (UVA)

紫外線の照射により短時間に硬化する接着剤である。 以前はラジカル重合系のアクリルオリゴマーを用いたも のが主流であったが7, 最近ではカチオン重合系のエポ キシオリゴマーを用いたものも開発されている。両者の 間には表 8 に示したような差があるとされており ${ }^{8}$, 硬 化物の物性はエポキシ系の方が優れている。

表 8 紫外線重合系の比較

\begin{tabular}{l|l|l}
\hline & \multicolumn{1}{|c|}{ ラジカル系 } & \multicolumn{1}{c}{ カチオン系 } \\
\hline 樹脂 & $\begin{array}{l}\text { アクリレート } \\
\text { ウレタン } \\
\text { ポリエステル など }\end{array}$ & $\begin{array}{l}\text { エポキシ } \\
\text { ビニルエーテル など }\end{array}$ \\
\hline 反応機構 & フリーラジカル & $\begin{array}{l}\text { ルイス酸 } \\
\text { ブンステット酸 }\end{array}$ \\
\hline 硬化スピード & 速い & 中位 \\
\hline 酸素阻害 & あり & なし \\
\hline 硬化収縮 & かなり顫著 & 少ない \\
\hline 接着性 & 中位 & 良好 \\
\hline 耐熱性 & 中位 & 良好 \\
\hline
\end{tabular}

a) アクリル系

当初は紫外線の透過する材料（ガラスなど）のみにし か使用できなかったが，加熱硬化性を付与するなどによ り金属相互の接着にも適用が可能となっている。図 1 に アルミニウム板を接着した時の温度の影蔇を示したが9), 金属の種類も影響するとされている。

けん気硬化性を付与したものやプライマーを用いるむ
のもある ${ }^{10)}$ 。た，最近では可視光でも硬 化するものが開発されている11)。

b)エポキシ系

スルホニウム塩を光重合開始剤としたも ので, 紫外線の照射によって生じるカチオン により重合が開始するものである12)。以前 にはジアゾニウム塩なども検討されていた。 硬化反応はアクリル系よりも遅く，暗反 応性があるなどの利点を生かした適用がな されている。

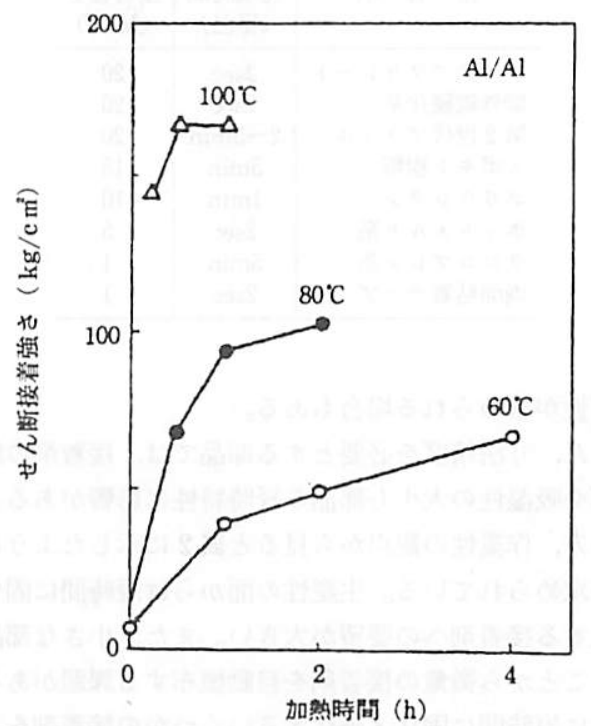

図 1 紫外線硬化系接着剤の加熱硬化性

\section{2 汎用接着剂}

エポキシ樹脂の一部もこの範瞦に含まれるが, 金属や プラスチックの接着に用いられている接着剤を紹介する。

1) 第二世代アクリル系 (SGA)

アクリルオリゴマーをベースとした接着䬉の一つであ るが ${ }^{13)}, 2$ 液主剤タイプとプライマータイプの 2 系列が ある。比較的短時間に硬化し, 得られる接着強さが大き いことから金属の接着にも用いられている4)。また, 2 液性のものでも計量や混合にエポキシ樹脂ほどの精密さ を必要としない利点もある。しかし, 硬化前に密封する と金属を腐食することがあるので注意が必要である。

2）シアノアクリレート系

短時間に硬化する接着剤の代表的なものであり多くの 材料と良く接着するが，ポリオレフィンとエンプラの接 着にはプライマーを併用することが望ましい14)。

3）ホットメルト系 (HMA)

熱可塑性ポリマーをべースレジンとしたもので，加熱・ 溶融したものを塗布することが必要であるものの ${ }^{15)}$, 短 
時間に固化する利点がある。フイルムにしたあのあ市販 されている。ベーンレジンには EVA が広く用いられて いるが, 電子部品には耐熱性のあるポリアミドやポリエ ステル系のものが用いられている。

4) シリコーン系

ジメチルシロキサンを骨格構造に持つあのであるが, 接着剤の組成や硬化条件などにより多くの種類の接着剤 が市販されているが16), 多用されているのは計量や混合 を必要としない1液性のものである。

室温で硬化（RTV）する1液性のものは, 吸収した 水分により硬化が進行するすので，放出する成分により いくつかの種類がある。電子部品には腐食性のないアセ トンやアルコール系のものが適している。

一方, 加熱を必要とするもの（LTV）では，硬化に 必要な触媒がアミンやはんだフラックスと接触すると失 活して硬化不良となることがあるので, 表面の清浄度に 注意か必要である。

硬化物は耐熱性があり低温まで柔乾性のあることから, 熱膨張率に差のある材料の接着に適している。また, 電 気特性にも優れていることからプリント配線板のコーティ ングなどにも多用されている。表 9 には 1 液加熱硬化系 の代表的な用途を示した ${ }^{17}$ 。

表 $9 \quad 1$ 液加熱硬化シリコーン接着㓮の用途

・高圧回路部品の絶緑シール

・各種電気・電子部品の接着・シール

・ブリント基板のディップコート

・ハイブリッドIC, パワーモジュールなどの接着・シール

・電球型虽光灯の接着・シール

・ディスプレイ装渭高圧部などの絶縁シール

・シリコーンゴム成型品の接着

(パッキングの接着, 七ラミック容器との接着など)

・コイル, コンデンサーなど, 秦子の緩衛材

・スクリーン印刷によるフレキシブルブリント基板の絶緣 パインダー

・ドットプリンターヘッド部の放熱用充填

・サーマルヘッド部の放熱シール

- PBT, PPS 樹脂成型品の接着

・熱応力, 熱膨張による異材質間のストレス䌅衡材

・ガスケット類の耐熱コーティング

・尉熱ガラス製品の接着・シール

\section{5）両面粘着テープ}

アクリル系の粘着片を不織やプラスチックフイルムな どの両面に塗布したものであり，貼り合わせるとただち に接着強さの発現する利点があるが, 接着強さの小さい ことや温度特性が覀いなどの欠点もある。

一方, 絶縁用の粘着テープは紙やプラスチックフイル ムの片面に粘着剤を塗布したものであるが ${ }^{18}$, 耐熱性の 必要なものにはシリコーン系の粘着㓮が使用されている。 また, 電気絶縁用に用いる粘着剂には電食性の試験が行
われている19\%。

\section{3 接着剤の選択}

数多く市販されている接着剤の中から, 使用目的に適 した接着剤を短時間に選択するのは困難であり, 接着剤 メ一カの協力を得ることが望ましい。代表的な選択の手 順を表 10 に示した。

\begin{tabular}{|c|c|}
\hline 1 次 & $\begin{array}{c}\text { 被着材の種類 } \\
\text { 表面処理 }\end{array}$ \\
\hline 2 次 & $\begin{array}{l}\text { 接合部の設計 } \\
\text { 必要な接着強さ } \\
\text { 加わる力の種類 } \\
\text { 接着可能な面積 } \\
\text { 作業方法 }\end{array}$ \\
\hline 3 次 & $\begin{array}{l}\text { 使用環境 } \\
\text { 温・湿度 } \\
\text { 温度サイクル } \\
\text { 振 動 } \\
\text { 負 荷 } \\
\text { その他 }\end{array}$ \\
\hline
\end{tabular}

使用環境下での耐久性の評価には長時間を必要とし, 加速することも容易でないことが多い。負荷が接着面に 加わる場合には, 温度の影響が大きいことに注意が必要 である。

エポキシ樹脂接着剤の屋内での経時特性を図 2 に ${ }^{20)}$,

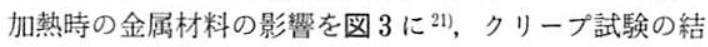
果を図 4 に ${ }^{22}$ それぞれ示したが, 安全係数をどの程度 にするかは接着強さのみでなく, 部品や機器の特性を総 合的に検討して判断することが望ましい。

\section{4. 接着剤の適用事例}

接着㓮を用いて組立てた電子部品の用途は電子・電気 機器のみならず, 自動車や航空機から宇宙用機器にまで 及んでいるので, 最終の用途を確認しそれに適した評価

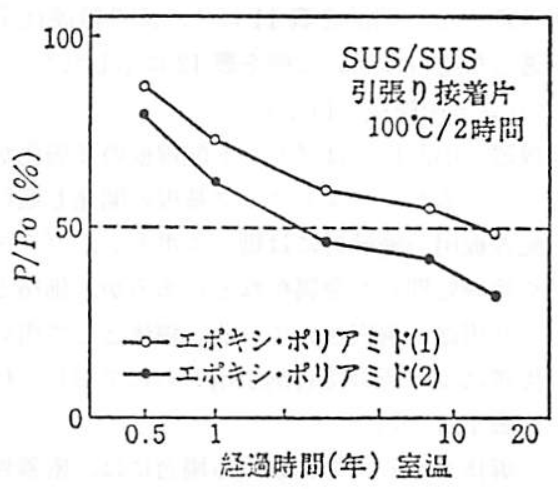

図 2 エポキシ系接着剤の経年变化 


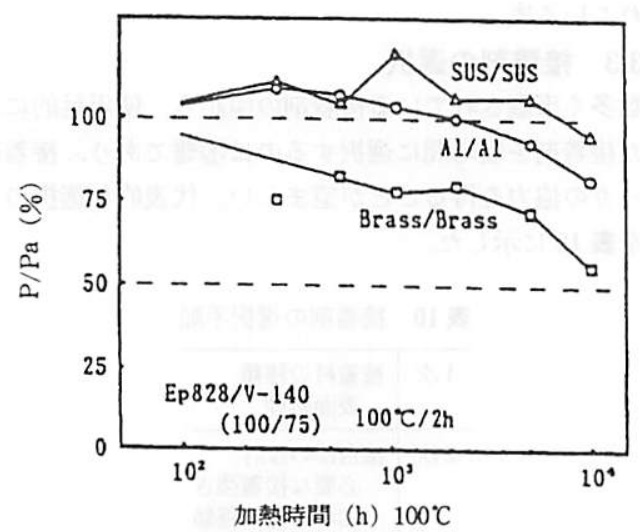

図 3 エポキシ樹脂接着剤の耐熱性に及ぼす被着剤の影響

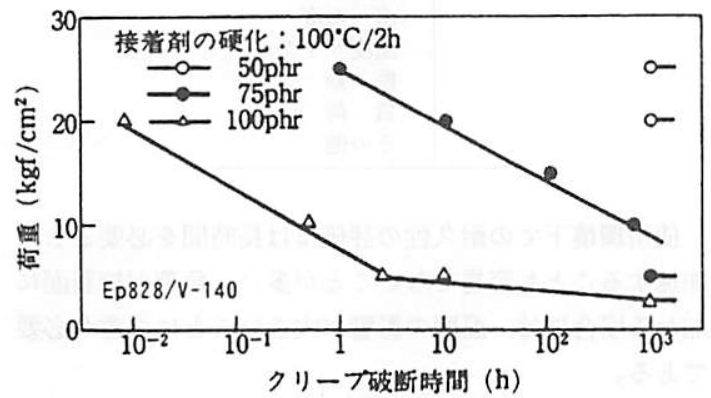

図 4 エポキシ樹脂系接着剤添加量とクリープ破断時間 $\left(80^{\circ} \mathrm{C}\right)$

試験をすることが望ましい。

機器の小形化による温度上昇やはんだ付け作業の温度 上昇などへの対応も，接着剤だけでなく周辺に用いてい る有機材料全般に必要である。

ここでは, 汎用部品と精密部品に大別して接着剤の適 用事例を紹介する。

\section{1 汎用部品}

汎用の電子部品には多くの種類があるが, エポキシ樹 脂を接着剤とした部品を表 11 に ${ }^{23)}$, 紫外線硬化系接着 剤を不透明な材料に用いた例を表 12 に示した9\%。

1) プリント配線板 (PCB)

電子機器の小形化にはプリント配線板の多層化が大き く寄与しているが, ビルドアップ基板の開発む進行して いる。配線板用の絶縁材には紙/エポキシ，ガラス／エ ポキシや絶緣処理した金属板などがあるが，価格と特性 などにより用途が選択されている。導体として用いる銅 はくの接着には各種の接着剤が用いられており, 代表的 なものを表 13 に示した。

また，導体をめっきで作成する場合には，密着性の改 善にエッチングなどの作業む行われている。
表 11 汎用部品におけるエポキシ樹脂接着剤の使用例

\begin{tabular}{|c|c|}
\hline 部 品 & 使用個所 \\
\hline 小形トランス & $\begin{array}{l}\text { コア (けい素鋼板) の積層 } \\
\text { フェライトコアの接着 } \\
\text { 安定期の注形 }\end{array}$ \\
\hline スピーカ & $\begin{array}{l}\text { マグネットの接着 } \\
3 \text { 点部の接着 }\end{array}$ \\
\hline $\begin{array}{l}\text { プリント } \\
\text { 回路基板 }\end{array}$ & $\begin{array}{l}\text { 積層用プリブレグ } \\
\text { チップ部品の固定 } \\
\text { 導電性接炭剂によるダイボンディング }\end{array}$ \\
\hline ブラウン管 & バンドの固定 \\
\hline 電球 & 口金の固定 \\
\hline 半導体 & 導電性接着剤によるダイボンディング \\
\hline 小型モータ & $\begin{array}{l}\text { フェライトコアの接着 } \\
\text { コイル端末の固定 }\end{array}$ \\
\hline $\mathrm{X}$ 線検出器 & $\begin{array}{l}\text { 電極板の固定 } \\
\text { 気密シール }\end{array}$ \\
\hline 超音波探触子 & $\begin{array}{l}\mathrm{PZT} \text { の接着 } \\
\text { マッチング層の接着 }\end{array}$ \\
\hline
\end{tabular}

表 12 不透明な材料の接着事例

・チップ部品の固定

・ボルト, ネジの固定

・部品の仮固定, シール

・トランス,コイル類のリード線の固定

・磁気へッドのコイルの固定

- CD 用部品の固定

・モータブラシの固定

・圧電素子の組立

・電球の組立

・スピーカの組立

・マイクロフォンの組立

・コンデンサーの封止

・電子レンジ用ドアスクリーンの組立

・DVD 板の貼り合わせ

・部品のポッティング

・ジャンパー線の固定

表 13 銅はく用接著剤の種類

1. PVB変成フェノール樹脂

2. NBR 変成フェノール樹脂

3. 変成エポキシ樹脂

4. ナイロン変成エポキシ樹脂

5. エポキシプリプレグ

6. 熱可塑性ポリイミド

7. 熱硬化性ポリイミド

接着剤にははく離接着強さとはんだ付け温度 $\left(260^{\circ} \mathrm{C}\right)$ でふくれの生じないことが求められているが, 誘電率な どの電気特性に加えて金属への腐食性のないことも必要 とされる。

携帯電話機などに多用されているビルドアップ基板で 
は層間の絶縁材にエポキシ樹脂が用いられている24)。絶 縁層の穴明けが上下の回路の接続に必要であり, 熱硬化 系 /レーザと光硬化系/フォトプロセスの 2 つの方式が あるが前者の方が生産性が高いとされている。

多層配線板ではスルーホールの銅めっきの密着性の向 上も一つの課題とされている。

配線板に搭载する各種の部品も小形化がなされており, 表面実装の技術が進展している。チップ部品には仮固定 用の接着剤として, 短時間に硬化するエポキシ樹脂が多 用されている。また, 樹脂モールドした ICに代わって モールドレスのベアチップの適用が増加しており, 導電 性接着剤やアンダーフィルレジン，チップコートレジン などにエポキシ樹脂が用いられている25)。

ポリイミドフイルムなどを用いたフレキシブル配線板 (FPC) あ各所に採用されている ${ }^{26)}$ 。

2) 半欮体

電子機器の小形化には半導体の進歩の寄与も大きく, 内部配線の微細化にともない, 加工に用いているレジス トの高性能化が進んでいる。

前工程の終了したシリコンウエハーはダイサーを用い て所定の寸法に切断されるが, ウェハーの固定に使用す る粘着テープは紫外線の照射により粘着力の低下するす のが採用されており ${ }^{27)}$, 真空チャックによるチップの移 動を容易にしている。また，チップの表面にはポリイミ ドをはじめとして各種のレジンがオーバーコート材とし て用いられている。

後工程の最初はリードフレームへのダイボンディング である。以前は $\mathrm{Au}-\mathrm{Si}$ の材料が接合に用いられていた が, 最近では低温での作業が可能な導電性接着剂を用い る方法が主流である28)。

半導体のパッケージにはセラミックや金属のケースを 用いることもあるが, 中心はレジンモードである29)。 ジンにはエポキシ樹脂が用いられているが, 多くの改良 がなされて現在に至っている。表 14 に基本組成を示し たが ${ }^{30)}$ 大半は充てん剂のシリカであり，有機物は $20 \%$ に満たない数值である。金型との離型に必要な離型剤が リードフレームやチップとの密着性を低下させているこ とあある。

また、レジンにはイオン性不純物の少ないことやリフ ローのはんだ付け作業でレジンにクラックの発生しない ように吸湿性の小さなものが求められている。

一方, 実装密度を高めるためにパッケージのないベア チップを用いることも増加しており， TAB や FCB な どの方式が検討されている。はんだに代るものとして導 電性接着剤の利用も検討されている31)。

高出力のモジュールでは温度上昇を避けるために放熱
表 14 半尊体用モールドレジンの基本組成

\begin{tabular}{|c|c|}
\hline 成 分 & 配合比 (wt\%) \\
\hline ベースレジン（ピフェニル） & 8.3 \\
\hline 硬化剂（フェノール） & 7.3 \\
\hline 硬化触媒 & 0.4 \\
\hline 充てん剂（溶融シリカ） & 80.0 \\
\hline 難燃化剂（Br-ノボラック） & 1.5 \\
\hline 難燃助鼡（Sb203） & 1.5 \\
\hline 離型㨈（カルナバワックス） & 0.2 \\
\hline
\end{tabular}

が必要であり，熱伝導性のグリースや接着阂を利用した 放熱フィンが用いられている。一部では水冷の放熱も採 用されている。

3）小形トランス・コイル

トランスのコア材の積層や固定にはエポキシ樹脂が主 に用いられているが, フェライト材では接着䬉のストレ スでクラックの発生することもあり注意が必要である。

コイルの固定や端末の処理には HMA やUVA 系の 接着凪の他に粘着テープも用いられている。VTRのロー タリートランスでは, コイルの固定に使用した接着剤の 誘電率の大小が問題となった。

自己融着線の表面にはポリアミド系の接着層が塗布し てあり, 通電加熱などの手法で線材の固定やコイルの成 形がなれている。

機器の温度上昇に対応して線材の絶縁用エナメルにつ いても改良が加えられており，はんだ付け作業の可能な ポリエステル系の材料む開発されている32)。

4) 音響部品

スピーカや圧電甞子など電気信号を音に变換するもの が数多くあるが, 組立てには接着剤が必要とされており, コーンを用いた一般のものでは 10 個所以上の接着部所 がある5。接着㮁にはゴム系, SGA，エポキシ，紫外線 硬化系などが用いられている。小形化や高出力化に対応 するために従来よりも耐熱性を必要とする個所が増加し ている。

コーンの材料には紙や繊維強化紙，プラスチック，金 属など各種のものが用いられいるが, 接着剤もこれらの 材料に適したものか使用されている。LCP 用いるこ とも検討されている ${ }^{33)}$ 。

一方, 磁気回路などの金属部分にはエポキシ樹脂や SGA が用いられている。また, ボイスコイルの周辺に はエポキシ樹脂系の中であ, 特に耐熱性のあるものがボ ビンとコイル巻線の間に適用されている。

レコードや磁気テープに代わって, 光を情報の記録と 再生に用いる各種の機器が開発され，ディスクが情報を 記録する支持体として使用されている。表 15 に代表的 なものを示したが，最近ではCDやDVDでも使用者 
表 15 ディスクの種類と構成

\begin{tabular}{|c|c|c|c|c|}
\hline 種類 & 材料 & 舐録材料 & 構成 & 接着郕 \\
\hline $\mathrm{CD}$ & $\mathrm{PC}$ & - & 1 枚 & - \\
\hline VD & PMMA & - & 2 枚 & 粘着剤 \\
\hline MD & $\mathrm{PC}$ & 金属 & 1 枚 & - \\
\hline DVD & PC & - & 2 枚 & $\begin{array}{c}\text { 粘着㓮 } \\
\text { UVA } \\
\text { エポキシ }\end{array}$ \\
\hline $\begin{array}{c}\text { 光ディスク } \\
(\mathrm{MO})\end{array}$ & $\begin{array}{c}\text { ガラス } \\
\text { PMMA } \\
\text { PC } \\
\text { エポキシ } \\
\text { 他 }\end{array}$ & 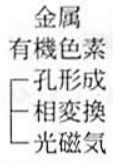 & 2 枚 & $\begin{array}{c}\text { エホキシ } \\
\text { UVA } \\
\text { 粘着剤 } \\
\text { SGA }\end{array}$ \\
\hline
\end{tabular}

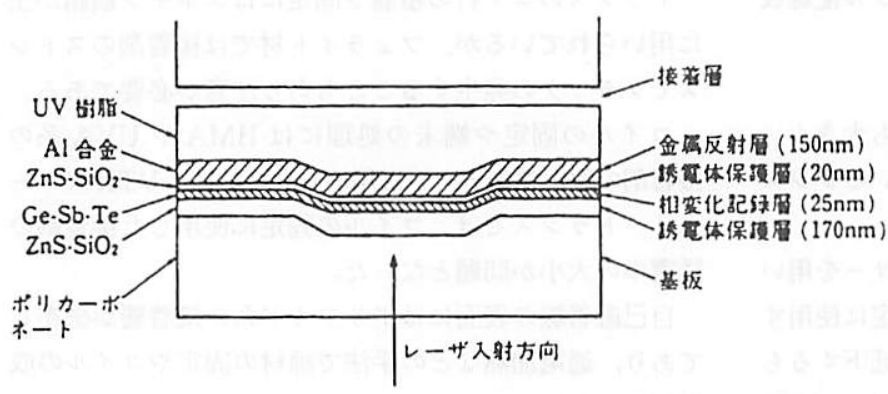

図 5 DVD-RAM ディスクの断面構造

表 16 DVD の接着方式の種類

\begin{tabular}{|c|c|c|c|c|}
\hline 方式 & スクリーン印刷 & スピンコート & ロールコート & *ート \\
\hline 接着珮 & UV 硬化 & UV 硬化 & ホットメルト & 両面粘着テープ \\
\hline 主成分 & エポキシ采 & アクリル重合 & ポリエステル系 & アクリル系 \\
\hline 反応形 & カチオン重合 & ラジカル重合 & - & - \\
\hline 反応性 & 荤硬化 & 速硬化 & - & - \\
\hline 安定性 & 0 & $\triangle$ & 0 & 0 \\
\hline 接着性 & 0 & 0 & 0 & 0 \\
\hline 耐熱性 & 0 & 0 & $x$ & $\triangle$ \\
\hline 形状保持性 & 0 & $\triangle$ & $\triangle$ & 0 \\
\hline 材料歩留 & 0 & $\triangle$ & $\triangle$ & $x$ \\
\hline
\end{tabular}

が情報の記録を行えるもの（CD-R など）が開発され ている。

記録材料には有機色素や金属（相变換，光磁気）など が用いられいる。図 5 に相変換の記録膜を用いた DVD 用ディスクの断面構造の例を示したが ${ }^{34)}$ ，高密度記録へ の材料の開発がなされている。

2 枚のディスクを貼り合わせている代表例は DVD で ある。ディスクの材料はポリカーボネートが中心である
が, 接着する面は保護膜として用いた紫外線硬化樹脂で あることが多い。ディスクの接着には表 16 に示したよ うな方式が検討されているが35), 生産性の点からカチオ ン重合系の紫外線硬化エポキシが注目されている36)。

\section{2 精密部品}

接着剤を用いて組立てた部品においてもミクロン単位 の寸法安定性を必要とする部品が增加している。接着剤 のベースレジンには吸湿性の小さなものを選択し，シリ カなどの充てん剤を配合して熱膨張率の低隇を図ったも のが多い。

エポキシ樹脂と紫外線硬化系の接着骺が多用されてい るが，硬化時の応力が問題となることもあるので注意が 必要である。

表 17 にはエポキシ樹脂の適用例を示 したが37)，作業性などから紫外線硬化系 に変更されているものもある。

1) 磁気へッド

磁気記録で情報の記録と再生に用いる あので各種の磁性材料の接着に接着剤が 使用されている。へッドには用途により 表 18 に示したような適用個所があり， エポキシ樹脂の用いられている例が多い。 一部ではガラスを用いた接着む行われて いる。薄膜へッドでは層間の絶縁材にポ リイミドが適用されている。

磁気材料の特性が接着剤からの応力で 変動することがあるので注意が必要であ る。

2) 光ヘット

レーザ光を用いてディスクへ情報の記 録と再生に使用するむので，CD や DVD， 光ディスクなどに用いられている。CD に用いられているむのの基本構造を図 6 に ${ }^{38)}$ ，最近の製品の写真を図 7 にそれぞ れ示した。小形化と軽量化が図られてい る。

レンズやプリズムなどをアルミニウム やエンプラ製の筐体に接着・固定するこ とが作業の主であり，接着剤からのひずみが大きな課題 とされている。図 8 に検討結果の一例を示した ${ }^{39}$ 。紫外 線硬化系ではエネルギーの大きな光で硬化すると接着部 のひずみが大きくなることむ報告されている。

接着剤の弾性率や収縮率, 塗布量, 塗布する場所など がプリズムなどの光学特性に影響するので，十分な検討 が必要とされる。位置の精度を必要とする場合には硬質 で吸湿性や熱膨張率の小さな接着剤を必要とする。 
表 17 精密部品におけるエポキシ樹脂接着剤の適用例

\begin{tabular}{|c|c|}
\hline 部 品 & 適用個所 \\
\hline 磁気へッド & $\begin{array}{l}\text { コアの積層接着・固定 } \\
\text { バネの固定 } \\
\text { スライダーの積層・固定 } \\
\text { ケースへの固定・注形 } \\
\text { FPCの固定 }\end{array}$ \\
\hline 光コネクター & $\begin{array}{l}\text { ファイバーコアの固定 } \\
\text { ファイバーの固定 } \\
\text { 接続部の固定・保護 }\end{array}$ \\
\hline 光合分波器 & $\begin{array}{l}\text { レンズの接着・固定 } \\
\text { ブリスムの接着・固定 } \\
\text { ファイバーの固定 }\end{array}$ \\
\hline $\begin{array}{l}\text { 表示素子 } \\
\text { (LCD) }\end{array}$ & $\begin{array}{l}\text { ガラスセルの組み立て } \\
\text { 上下䨪極の接続 } \\
\mathrm{IC} \text { 実装 (COG) }\end{array}$ \\
\hline 光一 & $\begin{array}{l}\text { レンズ, プリズムの固定 } \\
\text { バネの固定 } \\
\text { コイルの固定 }\end{array}$ \\
\hline
\end{tabular}

表 18 磁気へッドと接着風の適用個所

\begin{tabular}{|c|c|}
\hline へット & 適用個所 \\
\hline オーディオ用 & $\begin{array}{l}\text { 磁性材料の積層 } \\
\text { 非磁性材料の接着 } \\
\text { 金属ヶースへの固定 } \\
\text { 端子部の補強 }\end{array}$ \\
\hline VTR 用 & $\begin{array}{l}\text { ヘッドチップの接着 } \\
\text { 端子板の接着 } \\
\text { 接着部の補強 }\end{array}$ \\
\hline ディスク用 & $\begin{array}{l}\text { 磁性材料の積層 } \\
\text { ジンバルへの固定 } \\
\text { ICへッドの固定 } \\
\text { FPCの固定 } \\
\text { 加工時の仮固定 }\end{array}$ \\
\hline
\end{tabular}

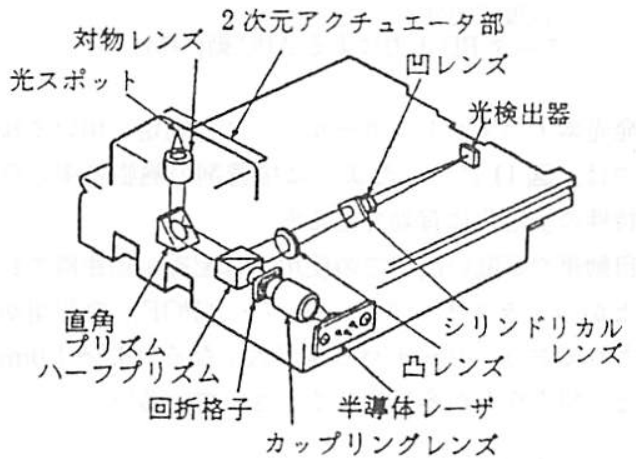

図6 コンパクトディスク用ピックアップの光学系構成図

3）表示菜子（LCD, ELD, PDPなど)

ブラウン管に代わって液晶表示素子（LCD）など平 面の表示素子の開発が進行しているが, いずれも平面ガ

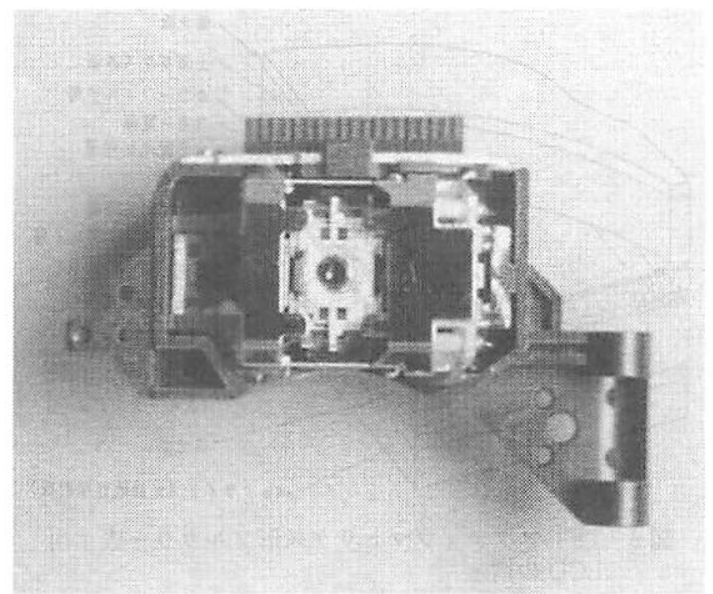

図 7 最近のCD 用光へッドの形状
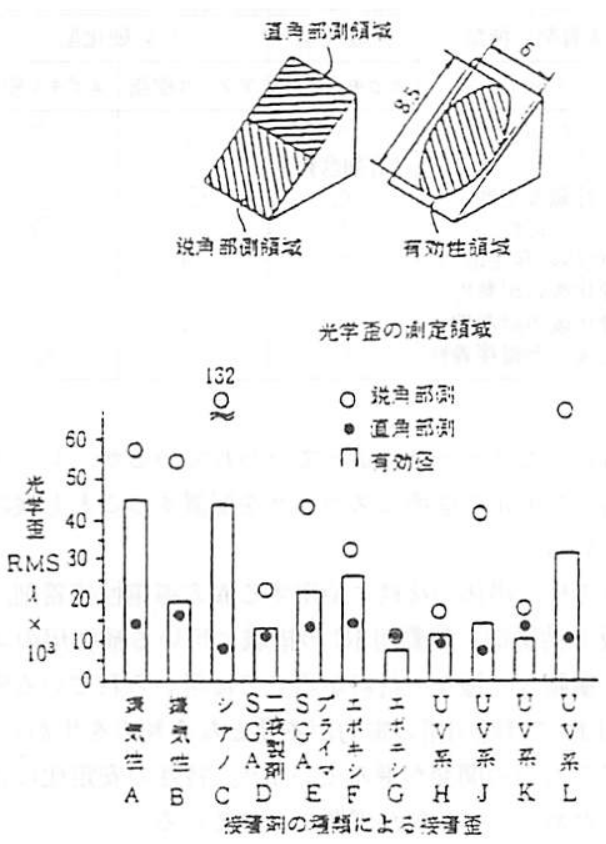

図 8 接着剤により発生する光学歪み

ラスを貼り合わせたものである。

LCD の断面構造を図 9 に示したが40)，ガラスの表面 には TFT やカラフィルター, PI の配向膜などが作成さ れており，5〜10ミクロンのギャップで貼り合わせた内 部に液晶を充てんしたものである。

貼り合わせに用いる接着剤には加熱硬化系のエポキシ 樹脂が以前から使用されているが，カチオン硬化の光硬 化エポキシ樹脂が最近になって注目されており，表 19 に示したような利点があるとされている ${ }^{41)} 。$

ギャップ幅の調整は接着剤に配合したスペーサや内部 


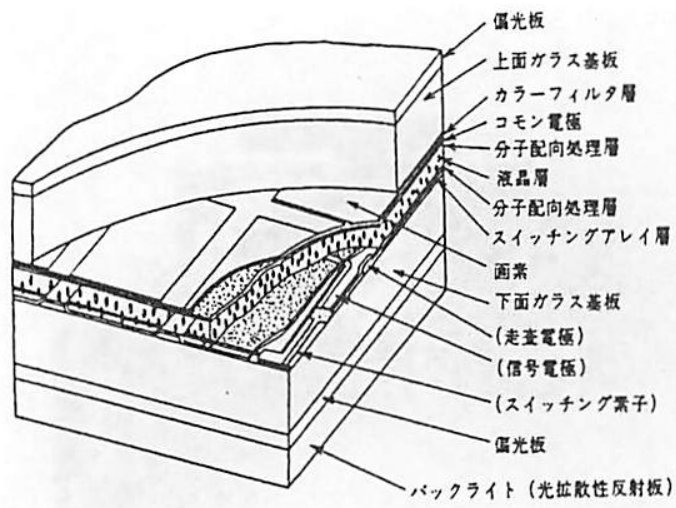

図9 TFT アクティブマトリクス形フルカラー表示用 LCD の構造

表 19 LCD セル組立用接着剤の特性

\begin{tabular}{|c|c|c|c|}
\hline 接着鼡の種類 & 熱硬化型 & \multicolumn{2}{|c|}{ UV 硬化型 } \\
\hline 主成分 & エポキシ樹脂 & アクリル樹脂 & エポキシ樹脂 \\
\hline 作業性 & $\begin{array}{c}\triangle \\
\text { (溶剤含有) }\end{array}$ & () & (2) \\
\hline 眝荿安定性 & $\triangle$ & 0 & () \\
\hline 反応性 & $\triangle$ & (2) & 0 \\
\hline 硬化時の発生応力 & $\triangle$ & (2) & 0 \\
\hline 硬化後の耐熱性 & (a) & $\triangle$ & (2) \\
\hline 硬化後の耐湿性 & (a) & $\triangle$ & (a) \\
\hline 硬化後の剥離接着性 & (a) & $\triangle$ & (a) \\
\hline
\end{tabular}

に散布したスペーサによって行われているが, レジスト を用いて所定の個所にスペーサを配置することも検討さ れている42)。

その他，導体の接続に使用する異方導電性接着剂，偏 光板の粘着剂, 駆動用 IC の搭载に用いる補強用のエポ キシ樹脂など種々の材料が組立てに用いられている ${ }^{43)} 。$

ELD では照明用の電力が不要となる利点を生かして, 小形のものの開発が進んでいる ${ }^{44)}$ 。特性の安定化には防 湿のためのシール材が課題とされている。

4) 光部品

電線を用いた電気通信に代わって，光ファイバーを用 いた光通信が情報伝達の中心となりつつあるが，使用す る部品の組立てには種々の技術課題が生じている ${ }^{45)}$

接着剤の中を光が通過する個所に用いる場合には，透 過率や屈折率の数值が問題となることから，ハロゲンを 導入した化合物を併用することが行われている。図 10 に屈折率の制御が可能な範囲を示した ${ }^{46)}$ 。

光ファイパーの接続はコネクターを用いる手法と直接 行う方法とあるが，いずれにも接着剤を用いられている。 コネクターでは接着が不十分であると接触面の平坦性が 低下して, 伝送ロスの增加することが知られている。

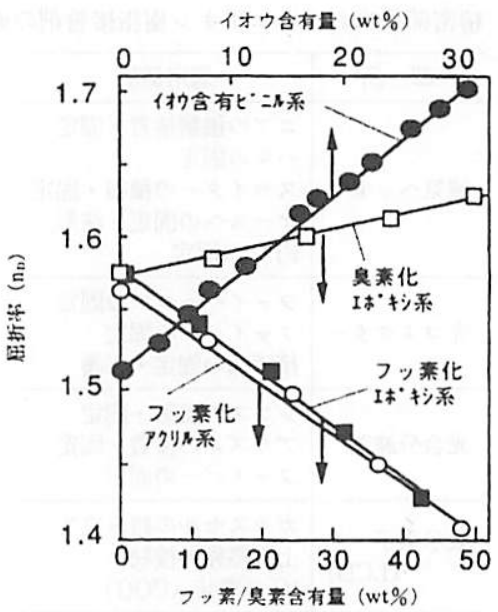

図 10 光学接着剤の屈折率制御範囲

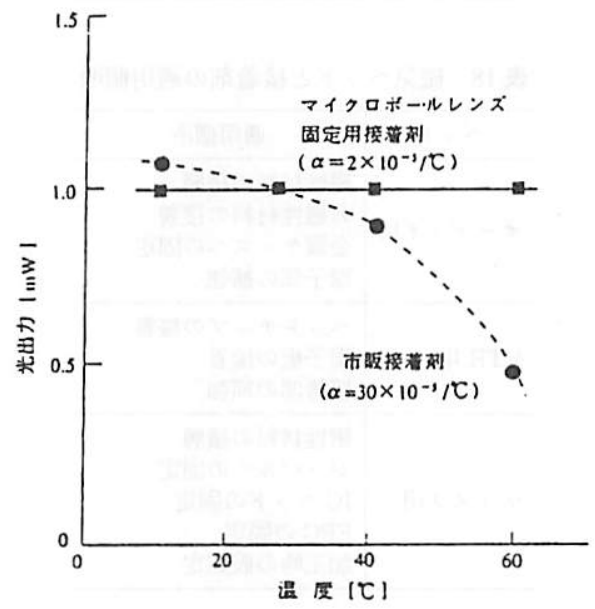

図 11 マイクロボールレンズ固定 LD モジュールの光出力 の温度安定性

(モニタ PD 出力による APC 動作特性)

発光素子のマイクロボールレンズの固定に用いる接着 剤では, 図 $11 に$ 示したように接着剤の熱膨張率の低減 が特性の安定化に有効である ${ }^{46)}$ 。

自動車や家庭の内部での使用には配線が短距離で良い ことからプラスチックファイバー（POF）の利用が検 討されており，ファイバー径が太くなる $(0.2 \sim 1.0 \mathrm{~mm})$ ことで組立作業が容易になるとされている47)。

\section{5.おわりに}

組立作業への接着剤の適用は今後も增加の傾向にある が, 使用目的に適した接着剤の選択が大きな課題であり, 作業性を無視することは出来ない。細分化された用途と なることも多いので, メ一カの協力を得て選定のスピー 
ドアップを図ることが不可欠である。電子部品では接着 剤を少量で一定の量を塗布し，短時間に硬化することが 求められており，1液性の接着剂へのニーズが大きい。

材料のリサイクルが大きな課題となりつつあるが，プ ラスチックの接着では素材のリサイクルに障害とならな いための配虑が必要である。

\section{引用 文 献}

1）英 一太, “電気・電子機器の接着設計”, 日刊工業新閉社 (1979).

2）柳原榮一、“接着技術のはなし”日本実業出版社 p. 141 (1997).

3）佐々木達也, 工業材料, 43(10), 83 (1995).

4）原賀康介, 工業材料，41(12)，176（1993）.

5）柳原榮一，日本接着協会誌，19(11)，497（1983）.

6）柳原榮一, 精密工学会誌, 52(2), 255 (1986).

7）実松徹司，加藤博之，日本接着協会誌，20(7)，300（1984）.

8）旦比野哲，堀江賢一，荒井佳英，工業材料，39(9)，86 (1991).

9）柳原榮一，接着の技術，19(3)，61（1999）.

10）原 修，日本接着学会誌，30(2)，80（1994）.

11）小林一男, 工業材料, 46(2), 66 (1998).

12）佐々木裕，ポリファイル，34(3)，44（1997）。

13）田口広一, 接着, 44(8), 362 (2000).

14）高橋 伸，材料科学，33(5)，206（1996）。

15) 2 の $\mathrm{P} 48$

16）荒井正俊, 工業材料， 41(12)，124（1993）。

17）信越化学工業（株）技術資料

18）柳原榮一，接着の技術，9(2)，36（1990).

19) JIS C 2107

20）柳原榮一, “接着技術の新展開” 工業調査会, p 64 (1985).
21）柳原榮一，未発表資料

22）柳原榮一，日本接着協会誌，17(4)，144（1981）。

23）柳原榮一，接着の技術，6(2)，25（1987）.

24）入野哲明，エレクトロニクス実装学会誌，2(6)，440 (1999)。

25）西口隆公, 水池克行, 電子材料, 35(7), 96 (1996).

26）徳光 明，エレクトロニクス実装学会誌，4(2)，113 (2001)。

27）高塚宏一, 川島裕次郎, 電子材料, 26(8), 69 (1987).

28）武田信司，增子 崇，晹佐正巳，宮寺康夫，日立化成テク ニカルレポート, No. 24 P 25 (1995)

29）鈴木 宏, 幸島博起, 河田達男, 市村茂樹, 日立化成テク ニカルレポート，No.19 P 23（1992）

30) 楠原明信, 坂 真澄, 石黑敏寿, 日本接着学会誌 35(4), 153 (1999).

31）榎戸政文, 師岡 功, 電子材料, 39(11)，81 (2000).

32）岡田秦典, 日立化成テクニカルレポート, No. 28 P 7 (1997).

33）馬場文明, 原 宏造, 村上 治, 成形加工, 10(8), 642 (1998).

34）後藤芳和, 精密工学会誌, 64(3), 376 (1998).

35）小南哲, エレクトロニクスと接着, 有機エレクトロニク 又材料研究会編, P 235（1998）

36）宮崎秀裕，丸山治久，電子材料，35(6)，56（1996）

37）柳原榮一, 防錆管理, 33(2), 56 (1989).

38）米澤成二, 山本節雄, 福井幸夫, 杉山俊夫, 日立評論, 65 (10), 703 (1983).

39）寺本和良, 西川哲也, 原賀康介, 日本接着協会誌 25(11), 512 (1989).

40）角田市良, 電子材料, $27(2), 37$ (1988).

41）饭田隆文，菊地明士，電子材料，39(6-別)，51（2000）。

42）小田原修一，電子材料 39(12)，49（2000）

43）戸田茂生, 日本接着学会誌, 37(4), 150 (2000).

44）浅田幹夫，電子材料，38(12)，45（1999).

45）村田則夫，光技術コンタクト，36(4)，202（1998）

46）村田則夫，接着の技術， 19(3)，30（1999).

47）井内 滋, 電子材料, 36(7), 55 (1997).

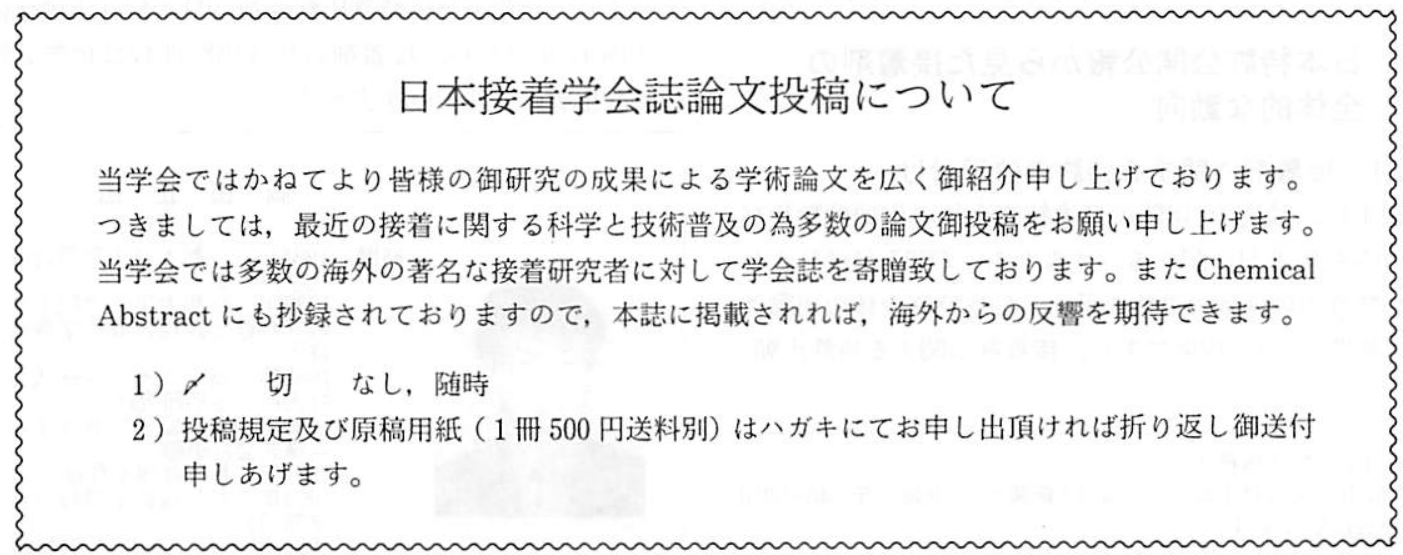

